\title{
Energy Use of Mediterranean Forest Biomass in Sustainable Public Heating Systems and its Effects on Climate Change - Case of Study
}

\author{
Juan Jose Mayans, ${ }^{a}$, , José A. Torrent-Bravob ${ }^{b}$ Leticia López ${ }^{b}$ \\ ${ }^{a}$ Government of the Province of Valencia, Service of environment, Water and Waste Department, Avda. \\ Peset Aleixandre 63, 46009 Valencia, Spain. \\ ${ }^{b}$ Department of Hydraulics and Environment, Investigation on Science and Forest Technology Group, \\ Polytechnic University of Valencia, Paraninfo $n^{\circ}$ 1, 46730 Grao Gandía, Valencia, Spain.
}

\begin{abstract}
The municipality of Serra, Valencia, located in the Spanish Mediterranean east coast, covers an area of 5,730 hectares, with $95 \%$ of this territory lying within the Sierra Calderona Natural Park and $85 \%$ being forest. The main axis of the municipality's economy has been the construction, reducing the primary sector, resulting in uncontrolled growth of forest and deterioration of the landscape. All this has raised forest fire risk to dangerous levels threatening the natural heritage of Serra and the future of the Serra Calderona Natural Park. The study shows how an adequate model of forest biomass management, through energetic use in sustainable public heating systems, can have positive direct effects in the fight against climate change, considering both economics aspects and environmental effects, and its capacity to contribute to the socioeconomic development of agro forestry regions, fixing its habitants and offering a rural development based on the rational use of their natural resources.
\end{abstract}

Keywords: biomass; renewable energy; forest management; public buildings; sustainable heating systems.

Article History: Received: 8th Nov 2020; Revised: 10th Dec 2020; Accepted: $16^{\text {th }}$ Dec 2020; Available online: $20^{\text {th }}$ Dec 2020

How to Cite This Article: Mayans, J.J., Torrent-Bravo, J.A., and López L., (2021) Energy use of Mediterranean forest biomass in sustainable public heating systems and its effects on climate change - case of study. Int. Journal of Renewable Energy Development, 10(2), 229-328 https://doi.org/10.14710/ijred.2021.34276

\section{Introduction}

In June 2012 the Region of Valencia, on the Spanish Mediterranean east coast, suffered one of the most devastating fires in its history, 50,000 hectares of forest and scrub were burned (MAPAMA 2019), economic losses amounted to 90 million euros (EFE 2012), plus the irretrievable loss of a pilot who died in action during extinction works. The ecological disaster has changed the face of the region forever (Pausas et al. 2017), where pine forests and crops once stood, now there's only desolation. This has accelerated the degradation of forest ecosystems, leading to further depopulation of rural areas (Preiss et al. 1997) and the abandonment of farms, jeopardizing the economic stability of the region (Martinho 2019) and consequently endangering social and ecological stability (Varga 2020).

At first view it seems obvious that the energetic use of biomass coming from sustainable forestry works (Kyriakopoulos 2010) encourages the survival of forests (Giménez 2018), reduces the effects on climate change, prevents forest fires (Regos et al. 2016), reduces traditional energy consumption (Streimikiene et al. 2020) and helps socio-economic development in agroforestry regions (Jekayinfa et al. 2020).
The municipality of Serra is a small mountain town in the province of Valencia on the Spanish Mediterranean east coast, whose altitude is approximately 330 metres above sea level. The town lies in the Camp de Turia region, on the southern slopes of the mountainous formation known as the Sierra Calderona. The municipality covers an area of 5,730 hectares, with $95 \%$ of this territory lying within the Sierra Calderona Natural Park and 85\% being forest (Generalitat Valenciana 2001).

The municipality of Serra, due to its location in the Sierra Calderona Natural Park has natural resources that together with its proximity to the provincial capital, grant it a privileged position from which to boost agricultural and forestry activities in line with others related to tourism and recreation, all of these being sustainable and complementary, as a new model of socio-economic development (Kyriakopoulos et al. 2018, Generalitat Valenciana 2001, Pawłat-Zawrzykraj et al. 2020, Giurea et al. 2018).

In 2010 the research team introduced to Serra's City Council the idea of an efficient management of the whole green waste of the municipality through the production of solid fuel, which could be used in the sustainable heating systems of public buildings (Kovolos et al. 2011, Deb et al. 2019, Martín-Gamboa et al. 2019, Zvingilaite et al. 2014). Applying the project to a population of 3,124 inhabitants

\footnotetext{
* Corresponding author: juanjo.mayans@dival.es
} 
(INE 2020) could demonstrate if the results obtained were consistent with the theoretical principles settled out.

The main objectives of the research were to demonstrate how a sustainable and efficient management of green waste from gardening (Deb et al. 2019), agricultural and forestry works (Giorio et al. 2019), had direct economic effects on green waste management and energy consumption (Nunes et al. 2020), and also it has been associated with positive collateral effects such as protecting the environment from forest fires (Morresi et al. 2019), decrease in greenhouse gas emissions (Visser et al. 2020), and local employment generation (Ronzon et al. 2020). In addition, the model proposed in Serra could be easily replicated in other municipalities and areas with similar characteristics (Bujdosó et al. 2012).

To achieve the above objectives, a prototype bio industry was built (Fig. 1) to collect, classify, treat and produce solid wood biofuel. Raw material has been green waste coming from both public and private parks and gardens, agricultural waste and other wood waste obtained from forest fire prevention works carried out in the Sierra Calderona Natural Park.

\section{$2 \quad$ Materials and Methods}

Due to existing raw material in the area, the chosen solid biofuel for this project was thus coming from green waste from gardening, agricultural and fire prevention forestry works. An excess of wood biomass is produced annually in the area as a result of public and private garden maintenance, traditional agricultural work and the necessary forest fire prevention work in the nearby mountains. The aim was to turn this excess of wood biomass, which was treated as green waste, into a resource usable as energy (Kyriakopoulos et al. 2013) Wood chips were the initial solid biofuel used, however issues caused by low density, low calorific power and high heterogeneity forced the change to wood pellets.

Green waste mixture composition and moisture has direct consequences on the quality of the wood biofuel (IDAE 2007) obtained and its energetic use capacity (Carrillo-Parra et al. 2020, Picchio et al. 2020, Miranda et al. 2015). In the early stages of the Project, raw material was largely composed of green waste from pruning predominant ornamental trees in the study area, such as Morus alba, Pinus pinea, Pinus halepensis, Melia azedarach, Jacaranda mimosifolia, Platanus acerifolia, Ceratonia siliqua. In later stages of the research, new wood waste coming from typical citrus agricultural pruning and other dryland fruit tree crops were incorporated, such as Citrus arantium, Olea europaea,
Prunus avium and Prunus dulcis. Finally wood waste coming from forest fire prevention works was added, with a composition of $90 \%$ of Pinus halepensis and $10 \%$ of short botanic interest shrubs.

Along the study, the composition of green waste used in solid wood biofuel production has evolved over the years (Table 1) and depending on its final destination. Thus, there are two different stages of production along the year, at the first stage (March to June) in which a lower quality biofuel is produced, the source of which is dominated by gardening waste, the destination of this solid wood biofuel produced is municipal facilities. At second stage (July to November) in which forest waste predominates and higher quality biofuel is produced for commercial purposes and it is also available to Serra's neighbours at a cost price.

The project presented two clearly differentiated but simultaneous phases. Phase one was the installation of sustainable biomass boilers as heating systems in municipal buildings and phase two was the implementation of a biomass prototype treatment plan, capable to produce enough solid biofuel (wood pellets) to cover Serra's public buildings heating needs.

\subsection{Phase I: Installation of sustainable heating system}

One of the main objectives was to improve Serra's independence of fossil fuels for heating through the use of their own resources. At the same time, it was necessary not to depend on a single wood biofuel, even if its origin was the same biomass coming from gardening, agricultural and / or forestry works. That is why the facilities provided in all cases, were sustainable heating systems, but able to admit different biofuels such as wood chips, wood pellets or even olive seeds and almond shells. Heating systems installed are capable, by easily modifying boilers consumption parameters, to use the whole variety of the most common solid biofuels existing in the market.

\subsubsection{Public nursery sustainable heating system}

Considering thermal needs of the building a $35 \mathrm{~kW}$ poly fuel biomass boiler was installed. The boiler has a steel body and vertical smoke evacuation with automatic cleaning system. It also has a compartment, large enough for ash accumulation with easy manual extraction. Its operation is fully automatic, so once it is running, regimes are automatic, depending on thermostat demand. The thermostat is located inside the building. Cleaning processes of smoke pipes and ash removal are also fully automatic. The boiler was located outside the building in an attached shed.

Table 1

Green waste treated composition evolution.

\begin{tabular}{lcccccc}
\hline \multicolumn{7}{c}{ Composition in \% of green waste treated in plant } \\
\hline Waste origin / year & 2012 & 2013 & 2014 & 2015 & 2016 & 2017 \\
\hline Gardening & 97 & 95 & 78 & 64 & 55 & 38 \\
Agriculture & 3 & 5 & 10 & 12 & 10 & 8 \\
Forestry & 0 & 0 & 12 & 24 & 35 & 54 \\
\hline
\end{tabular}


To efficiently distribute generated heat, a hot water circuit and iron radiators were chosen. In total, 21 heating points were installed with a total of 313 iron radiator elements measuring $878 \mathrm{~mm}$ x $92 \mathrm{~mm}$ x $60 \mathrm{~mm}$. A thermostat and a programmer device inside the building allows to control the temperature and operation of the whole heating system.

\subsubsection{Town Hall public building sustainable heating system}

In the Town Hall building the heating of all units was provided by using electric heat pump or individual oil or incandescent radiators both connected to the electric grid. Once the thermal needs of the building were determined, the installation of a poly biofuel biomass boiler was chosen. The boiler is identical to the one located in the municipal nursery, but with more power, in this case 65 $\mathrm{kW}$. The boiler feeds a 2,500-litre water accumulator which feeds three differentiated hot water circuits that are boosted by pumps to all radiators in the building. The boiler was placed in the basement for safety reasons and to easily full biomass silo from the outside. Each of the radiators installed has thermostatic valves so that when the radiator element reaches the temperature marked the valve closes until the temperature drops again, this allows to individually regulate the temperature according to the heat needs of each of the dependencies. Town Hall includes also a poly biofuel $12 \mathrm{~kW}$ stove to occasionally heat the main hall. It was acquired in 2016 and it is fully equipped with automatic cleaning system and programming options.

\subsubsection{Public school building sustainable heating system}

Serra's public school was built in 2010 and its heating system was a $100 \mathrm{~kW}$ gas-oil boiler and water circuit and radiators. According to the thermal needs of the building, a $150 \mathrm{~kW}$ automatic poly-biofuel boiler was chosen, the silo capacity is $3,000 \mathrm{~kg}$ of wood pellet. The regulation and control of the boiler can be managed out remotely and it allows alarm control and transmission via GSM-SMS.

\subsection{Phase II: biomass prototype treatment plant}

The very first step was to transform green waste into a biofuel that could be used in the mentioned sustainable heating systems, for that, a size reduction and homogenization of biomass was needed through crushing or chipping the raw material.

For that purpose an autonomous forest wood chipper was acquired, powered by a $65 \mathrm{HP}$ diesel engine and with a capacity to crush trees with a diameter up to $25 \mathrm{~cm}$. The fact that it was an autonomous towing wood chipper was crucial, since the project already considered in its beginnings the inclusion of green waste coming from forestry works. The final idea was to prevent forest fires, avoiding also the agricultural use of fire and so, reducing fire risk in the municipality of Serra.

To use wood chips in biomass boilers, humidity content should be below $30 \%$ and maximum chip size under $4 \mathrm{~cm}$, this left a large part of green waste out of energy use. This and the need to produce a more homogeneous solid biofuel, were the reasons why after a year of full operation with wood chips, it was decided to move into wood pellets.

Designing a biomass prototype plant capable of managing such green waste, required initial testing phases with different machinery to know every detail of wood pellet manufacturing process. For this purpose, manual pelletizers and fine grinders were tested for two years. During the first year a $7.5 \mathrm{~kW}$ power fine grinder with fine particle cyclone, and a small $7.5 \mathrm{~kW}$ power pelletizer were used, with a total production capacity of $100 \mathrm{~kg}$ of wood pellet per hour. To increase production, in 2014 , a $15 \mathrm{~kW}$ power pelletizer with production capacity between 200 and $250 \mathrm{~kg}$ of pellet per hour was acquired.

However, the difficulty of producing large quantities of wood pellets manually and the technical issues appeared drove to a mandatory investment to build a semiindustrial prototype wood pellet plant. Finally after years of testing with several solid biofuel production methods, in 2019 the biomass prototype treatment plant was operational and had the capacity (800 ton wood pellet/year) to produce enough wood biofuel to feed sustainable heating systems located in Serra's public buildings and also cover local demand.

Wood biofuel production data has evolved over the years as it follows. The excess of wood biofuel produced is stored to be used when needed or sold locally (Table 2). Production process of wood chips and wood pellets is represented by Fig 2.

Table 2

Wood biofuel production, consumption and storage evolution.

Tons of wood biofuel produced, consumed and stored

\begin{tabular}{lcccccc}
\hline & 2012 & 2013 & 2014 & 2015 & 2016 & 2017 \\
\hline Wood chips production & 322 & 493 & 565 & 475 & 606 & 551 \\
Wood pellet production & 0 & 22 & 38 & 49 & 138 & 282 \\
Wood chips consumption & 18 & 14 & 0 & 0 & 0 & 0 \\
Wood pellet consumption & 0 & 22 & 38 & 42 & 72 & 78 \\
Stored wood chips & 304 & 761 & 1,288 & 1,714 & 2,182 & 269 \\
Stored wood pellets & 0 & 0 & 0 & 7 & 73 & 277 \\
\hline
\end{tabular}




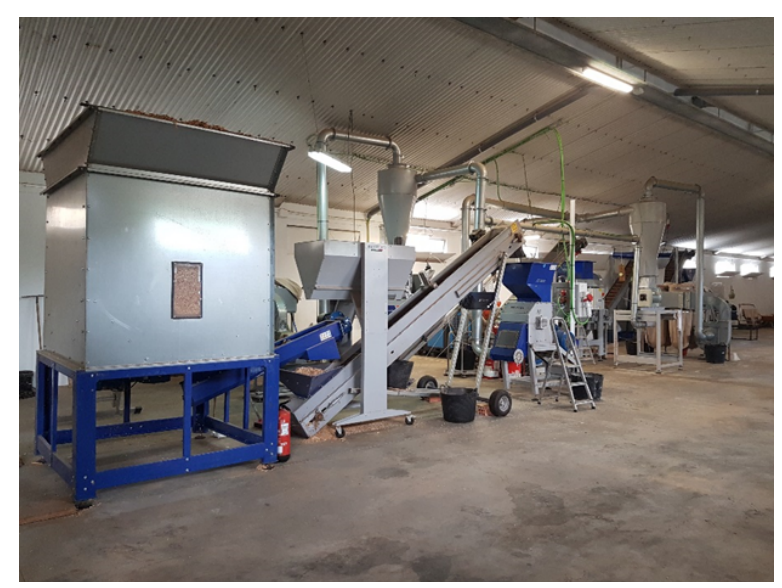

Fig. 1 Biomass prototype plant, production capacity 800 ton of wood pellet/year.

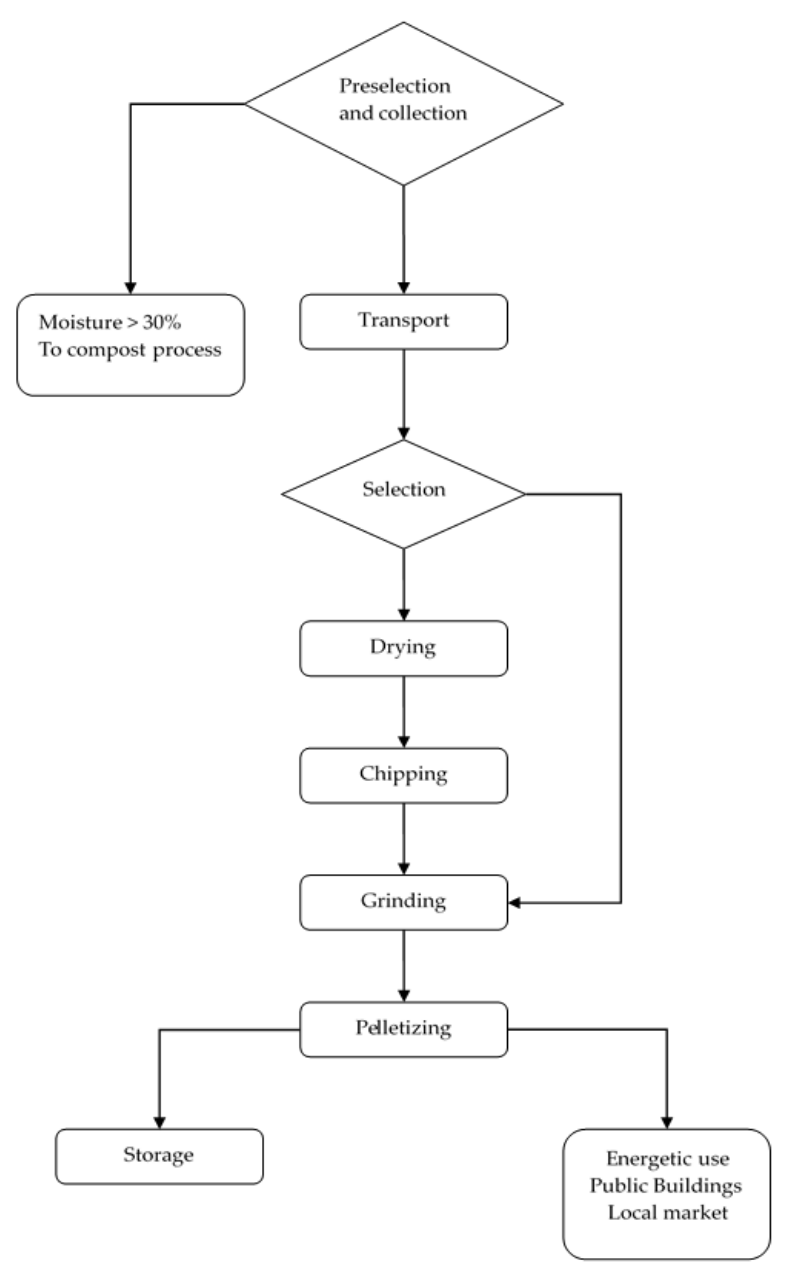

Fig. 2 Wood biofuel production scheme.

\section{$3 \quad$ Results}

\subsection{Economic results}

To quantify economic results in green waste management, the amount dedicated to green waste management during the years prior to the implementation of the project, specifically 2006 to 2010 , has been compared with billings for this same concept during the years in which the project has been in operation, 2011 to 2017. The same method has been followed to quantify economic savings in electric energy, comparing electrical invoicing in public buildings in which biomass boilers have been installed, between the years before and after the project was in operation. Likewise, kilowatts that are not consumed from electricity and therefore $\mathrm{CO}_{2}$ emissions that are being avoided by not using this type of energy, have been quantified. Finally, an economic study has been carried out for wood pellet surplus commercialization through direct sale to Serra's neighbours and the near market. All the economic benefits are directly earmarked for the generation of employment linked to the project.

Results show that in the period prior to the project implementation, years 2006 to 2011, the average cost of green waste management to Serra's City Council amounted to 58,935.90 euros. Since 2012, when the project was launched, a clear decrease in the cost of managing green waste has been appreciated, managing green waste is reduced to an average of $31,255.28$ euros per year. Thus the average annual savings in green waste management since 2012 has been $24,235.40$ euros per year.

With the evolution of annual savings obtained in management of the green waste, for the municipality of Serra. The following equation allows to obtain the annual savings in green waste management based on the tons of green waste generated in municipalities with similar geographical and population characteristics, and for tons of managed green waste under 2,000 per year, such as the municipalities within the Sierra Calderona Natural Park.

$$
\text { a.s. }=-0,0136 \cdot t^{2}+47,957 \cdot t+679,02(1)
$$

where:

- a.s.: Average saving in green waste management per year.

- $\quad \mathrm{t}$ : Average tons of managed green waste per year $(<2,000)$

Applying equation (1), Table 3 shows an approximation of the savings that these municipalities would obtain by applying to the green waste management municipality of Serra's solution.

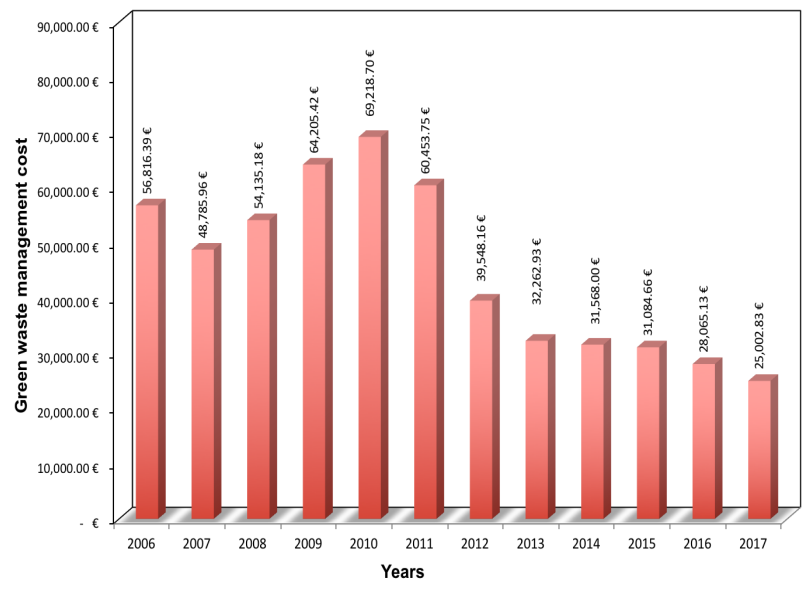

Fig. 3 Green waste management cost evolution. 
Table 3

Average savings in green waste management per municipality.

$\begin{array}{lcccc}\text { Municipality } & \begin{array}{l}\text { Municipality area } \\ \text { (Hes) }\end{array} & \text { Inhabitants (2016) } & \begin{array}{c}\text { Average tons of green } \\ \text { waste managed per year }\end{array} & \begin{array}{l}\text { Average saving in green waste } \\ \text { management per year }\end{array} \\ \text { Altura } & 12,950 & 3,621 & 687 & 27,206.70 € \\ \text { Segorbe } & 10,610 & 9,005 & 1,420 & 41,354.92 € \\ \text { Albalat } & 2,130 & 1,185 & 191 & 9,342.67 € \\ \text { Algimia } & 1,450 & 1,047 & 166 & 8,265.12 € \\ \text { Estivella } & 2,090 & 1,374 & 214 & 10,318.99 € \\ \text { Gilet } & 1,130 & 3,304 & 347 & 15,682.54 € \\ \text { Sagunt } & 13,240 & 64,439 & 1,982 & 42,304.59 € \\ \text { Segart } & 660 & 159 & 32 & 2,199.72 € \\ \text { Torres } & 1,180 & 644 & 101 & 5,383.94 € \\ \text { Gátova } & 3,040 & 366 & 73 & 4,107.41 € \\ \text { Marines } & 3,570 & 1,869 & 304 & 14,001.09 € \\ \text { Náquera } & 3,870 & 6,087 & 318 & 14,554.06 € \\ \text { Olocau } & 3,740 & 1,685 & 250 & 11,818.27 € \\ \text { Serra } & 5,730 & 3,070 & 590 & 24,239.49 € \\ \text { TOTAL } & \mathbf{6 5 , 3 9 0} & \mathbf{9 7 , 8 5 5} & \mathbf{6 , 6 7 5} & \mathbf{2 3 0 , 7 7 9 . 5 0 €}\end{array}$

So, those municipalities with larger areas and more inhabitants, therefore with a higher cost in waste management, would also be those obtaining greater savings by applying green waste management through the use of wood biofuel in sustainable heating systems, such as the case of the municipality of Serra. The total savings obtained in waste management in the whole municipalities within the Sierra Calderona Natural Park exceed 230,000 euros per year.

The economic savings from the non-use of electricity or carbon fuel (diesel) in municipal buildings old heating systems (Fig. 4, Fig. 5, Fig. 6) are obtained by comparing old and new energy bills in those public buildings where sustainable heating systems have been installed. The average energetic savings per year and public building are reflected on Table 4 .

These savings are somewhat lower than expected. It is also necessary to know that the green waste conversion into useful biofuel, has a cost which depends directly on the method used for biofuel production (Thek et al. 2004). Producing 49 tons of wood pellets manually costs $62,954.38$ euros and producing 282 tons of wood pellets in semi industrial prototype biomass plant costs $70,224.48$ euros.

Table 4

Average savings in green waste management per municipality.

\begin{tabular}{lc} 
Public building & Average savings per year \\
\hline Public Nursery & $2,435.76 €$ \\
Town Hall & $3,243.30 €$ \\
Public School & $15,491.78 €$ \\
Total & $\mathbf{2 1 , 1 7 0 . 8 4} €$ \\
\hline
\end{tabular}

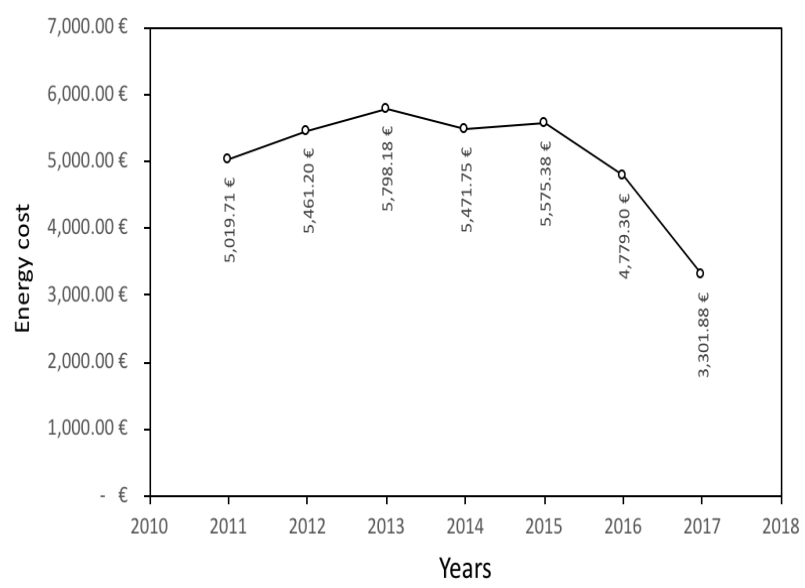

Fig. 4 Electricity cost evolution in public nursery.

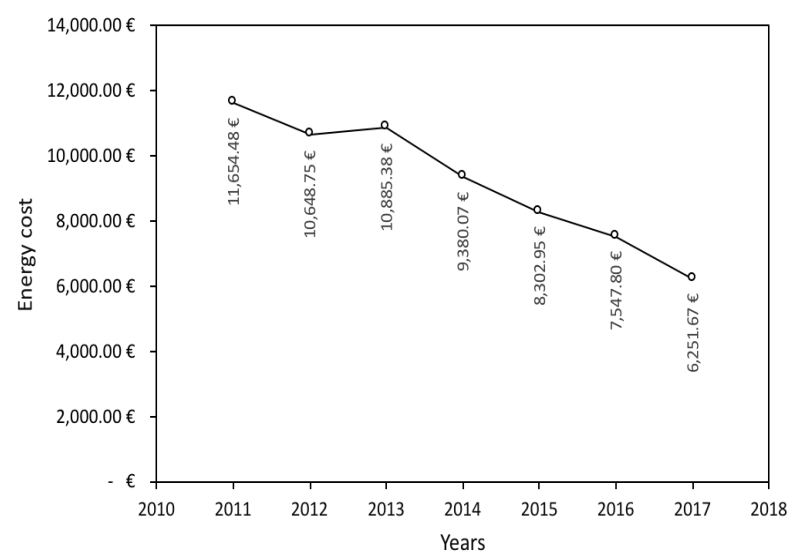

Fig. 5 Electricity cost evolution in Town Hall public building. 


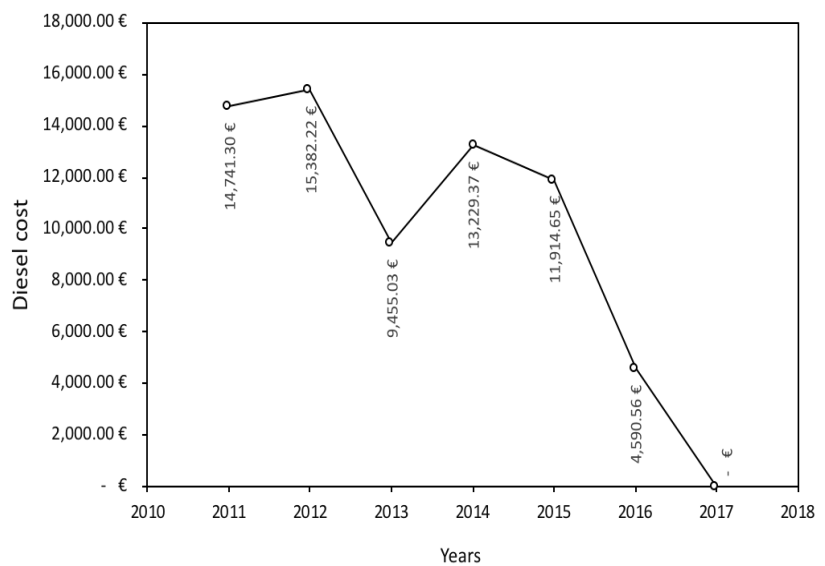

Fig. 6 Diesel cost evolution in public school.

Unlike the manual production method, the semi industrial production allows to generate a surplus of wood biofuel that could be sold in local market. Revenues obtained are added to the income account, making the project viable from a production of around 300 tons per year. For that purpose, it is necessary to increase the working hours by hiring more staff, so more employment linked directly to the project is created (Table 5).

One of the most important consequences of the implementation of a local economy circle in the municipality of Serra through the energetic use of green waste, is employment creation. So in the economic projection presented it is considered that two additional workers are needed to establish a double shift to achieve an annual production of 400 tons. Then a third shift would reach 600 tonnes per year, however, it is necessary to set up a forest brigade of 5 workers to feed production with forest raw materials.

Increasing production to the total capacity of the prototype plant, turns the project economically viable. The final balance for Serra's City Council in a ten year projection mounts up to $158,256.36$ euros, although it requires the hiring of at least 9 more workers (Table 5).

\subsection{Climate change results}

To calculate the reduction in $\mathrm{CO}_{2}$ emissions due to the decrease in electricity consumption in public buildings, it has been followed the recommendations of the Guide for Calculation of Greenhouse Gas Emissions version of March 1, 2018, published by the Catalan Climate Change Office of the Generalitat de Catalunya (OCCC 2018). More specifically, what has been developed in paragraph 2.1 dedicated to electricity consumption, which emphasizes that the calculation of emissions associated with electricity consumption requires the use of a factor called "electric mix" that is measured in grams of $\mathrm{CO}_{2}$ per Kilowatt hour and which is associated with electricity supply, ultimately, this factor considers the $\mathrm{CO}_{2}$ emissions associated with electricity generation, regardless of the origin of that energy.

Table 5

Economic projections year 1 to year 10 .

\begin{tabular}{|c|c|c|c|c|c|}
\hline & Year 1 & Year 2 & Year 3 & Year 4 & Year 5 \\
\hline Workers needed & & & & 2 more workers & \\
\hline Total Costs & $70,224.48 €$ & $71,077.38 €$ & $71,943.06 €$ & $85,458.29 €$ & $86,539.69 €$ \\
\hline Total production (kg) & 282,000 & 296,100 & 310,905 & 388,631 & 427,494 \\
\hline Local market production (kg) & 204,000 & 218,100 & 232,905 & 310,631 & 349,494 \\
\hline Selling price per $\mathrm{kg}$ & $0.18 €$ & $0.18 €$ & $0.19 €$ & $0.19 €$ & $0.19 €$ \\
\hline Savings & $45,406.24 €$ & $46087,33 €$ & $46,778.64 €$ & $47,480.32 €$ & $48,192.53 €$ \\
\hline Incomes & $36,720.00 €$ & $39,846.87 €$ & $43,190.02 €$ & $58,467.67 €$ & $66,769.31 €$ \\
\hline TOTAL BENEFIT & $11,901.76 €$ & $14,856.83 €$ & $18,025.60 €$ & $7,853.14 €$ & $15,596.04 €$ \\
\hline & Year 6 & Year 7 & Year 8 & Year 9 & Year 10 \\
\hline Workers needed & & 2 more workers & & 3 more workers & 2 more workers \\
\hline Total Costs & $87,637.31 €$ & $101,932.11 €$ & $103,260.62 €$ & $118,152.54 €$ & $237,610.47 €$ \\
\hline Total production (kg) & 470,244 & 587,805 & 646,585 & 775,902 & 931,083 \\
\hline Local market production (kg) & 392,244 & 509,805 & 568,585 & 697,902 & 853,083 \\
\hline Selling price per $\mathrm{kg}$ & $0.19 €$ & $0.20 €$ & $0.20 €$ & $0.20 €$ & $0.21 €$ \\
\hline Savings & $48,915.42 €$ & $49,649.15 €$ & $50,393.88 €$ & $51,149.79 €$ & $51,917.04 €$ \\
\hline Incomes & $76,060.44 €$ & $100,339.67 €$ & $113,587.46 €$ & $141,512.72 €$ & $175,573.13 €$ \\
\hline TOTAL BENEFIT & $24,320.04 €$ & $21,662.21 €$ & $33,930.32 €$ & $20,230.73 €$ & $-10,120.30 €$ \\
\hline
\end{tabular}


Table 6

Savings in $\mathrm{CO}_{2}$ emissions in public nursery due to sustainable heating system.

\begin{tabular}{rrrr}
\hline Year & $\begin{array}{r}\text { Real } \\
\text { electricity } \\
\text { consumption } \\
\mathrm{kW}\end{array}$ & $\begin{array}{r}\text { Real } \mathrm{C0}_{2} \text { emissions } \\
(\mathrm{kg})\end{array}$ & $\begin{array}{r}\text { Savings in } \mathrm{CO}_{2} \\
\text { emissions }(\mathrm{kg})\end{array}$ \\
\hline 2011 & 40,242 & $10,895.52$ & $1,559.79$ \\
2012 & 38,941 & $10,543.14$ & $2,982.09$ \\
2013 & 35,790 & $9,690.01$ & $3,406.26$ \\
2014 & 33,874 & $9,044.36$ & $3,802.97$ \\
2015 & 35,107 & $13,972.59$ & $5,702.68$ \\
2016 & 31,135 & $9,589.58$ & $5,134.77$ \\
2017 & 19,487 & $7,638.90$ & $8,863.25$ \\
\multicolumn{2}{r}{ Total savings in $\mathbf{C O}_{2}$ emissions (kg) } & $\mathbf{3 1 , 4 5 1 . 8 1}$ \\
\hline
\end{tabular}

Table 7

Savings in $\mathrm{CO}_{2}$ emissions in Town Hall building due to sustainable heating system.

\begin{tabular}{rrrr}
\hline Year & $\begin{array}{r}\text { Real } \\
\text { electricity } \\
\text { ronsumption } \\
\mathrm{kW}\end{array}$ & $\begin{array}{r}\text { Real } \mathrm{C}_{2} \text { emissions } \\
(\mathrm{kg})\end{array}$ & $\begin{array}{r}\text { Savings in } \mathrm{CO}_{2} \\
\text { emissions (kg) }\end{array}$ \\
\hline 2011 & 67,171 & $18,186.41$ & 0.00 \\
2012 & 55,771 & $15,100.00$ & 0.00 \\
2013 & 57,546 & $15,580.63$ & 929.76 \\
2014 & 49,440 & $13,200.48$ & $3,230.63$ \\
2015 & 43,765 & $17,418.27$ & $7,074.54$ \\
2016 & 42,314 & $13,032.71$ & $5,819.58$ \\
2017 & 37,289 & $14,617.29$ & $8,788.93$ \\
\multicolumn{2}{r}{ Total savings in $\mathbf{C O}_{2}$ emissions (kg) } & $\mathbf{2 5 , 8 4 3 . 4 3}$ \\
\hline
\end{tabular}

To calculate savings in $\mathrm{CO}_{2}$ emissions due to the sustainable heating system installed in public school building. It shall be used, what is published in paragraph 2.1 of the Guide for Calculation of Greenhouse Gas Emissions (OCCC 2018), concerning fossil fuels. In this case, for heating diesel fuel, emissions are $2.87 \mathrm{~kg}$ of $\mathrm{CO}_{2}$ emitted per liter consumed, with a diesel density of 900 $\mathrm{kg} / \mathrm{m} 3$ at $15^{\circ} \mathrm{C}$.

Savings in $\mathrm{CO}_{2}$ emission per building during the period of study, are $31,452 \mathrm{~kg}$ of $\mathrm{CO}_{2}$ at Public Nursery building (Table 6), 25,843 $\mathrm{kg}$ of $\mathrm{CO}_{2}$ at Town Hall building (Table 7) and $72,321 \mathrm{~kg}$ of $\mathrm{CO}_{2}$ at Public School building (Table 8 ). To these results we must add the savings derived from the sale, during year 2019, of solid wood biofuel in the local market (Table 9).

Table 8

Savings in $\mathrm{CO}_{2}$ emissions in Public School building due to sustainable heating system.

\begin{tabular}{rrrr}
\hline Year & $\begin{array}{r}\text { Real fuel } \\
\text { consumption } \\
\text { liters }\end{array}$ & $\begin{array}{r}\text { Real } \mathrm{CO}_{2} \text { emissions } \\
(\mathrm{kg})\end{array}$ & $\begin{array}{r}\text { Savings in } \mathrm{CO}_{2} \\
\text { emissions (kg) }\end{array}$ \\
\hline 2011 & 16,434 & 47,166 & 0 \\
2012 & 16,434 & 47,166 & 0 \\
2013 & 10,956 & 31,444 & 0 \\
2014 & 16,434 & 47,166 & 0 \\
2015 & 16,434 & 47,166 & 0 \\
2016 & 5,478 & 15,722 & 28,299 \\
2017 & 0 & 0 & 44,021 \\
\multicolumn{2}{r}{ Total savings in $\mathbf{C O}_{2}$ emissions (kg) } & $\mathbf{7 2 , 3 2 1}$ \\
\hline
\end{tabular}

Table 9

Savings in $\mathrm{CO}_{2}$ emissions due to the use of solid woo biofuel in local market.

\begin{tabular}{lc}
\hline Wood pellets sold in local market (ton) & 200 \\
\hline Wood pellet conversion factor & 2.5 \\
$\mathrm{CO}_{2}$ emissions per diesel liter (kg) & 2.87 \\
Savings in $\mathbf{C O}_{2}$ emissions (kg) & $\mathbf{2 2 9 , 6 0 0}$ \\
\hline
\end{tabular}

\section{Table 10}

Maximum Savings in $\mathrm{CO}_{2}$ emissions due to the use of solid wood biofuel in local market.

\begin{tabular}{lc}
\hline Wood pellets sold in local market (ton) & 1000 \\
\hline Wood pellet conversion factor & 2.5 \\
$\mathrm{CO}_{2}$ emissions per diesel liter (kg) & 2.87 \\
Savings in $\mathrm{CO}_{2}$ emissions (kg) & $\mathbf{1 , 1 4 8 , 8 0 0}$ \\
\hline
\end{tabular}

Table 11

Savings in $\mathrm{CO}_{2}$ emissions due to sustainable heating systems in public buildings.

\begin{tabular}{lc} 
& Savings in $\mathrm{CO}_{2}$ emissions (kg/year) \\
\hline Nursery & 8,863 \\
Town Hall & 8,789 \\
Public school & 44,021 \\
Total & $\mathbf{6 1 , 6 7 3}$ \\
\hline
\end{tabular}

Therefore, savings in $\mathrm{CO}_{2}$ emissions during the period of study have been quantified at $359,216 \mathrm{~kg}$. That quantity should rise up as the production of wood pellets is increased according to Table 10. Whereas maximum biomass prototype plant maximum around 800-1000 tons per year and considering that $\mathrm{CO}_{2}$ emissions per year in public buildings are stabilized in the quantities showed in Table 11.

Maximum savings in $\mathrm{CO}_{2}$ emissions, would be 1,209,673 tons per year. Therefore, $\mathrm{CO}_{2}$ emissions avoided, per year, considering all sustainable heating systems in the municipality of Serra and the sale of wood pellets, according to Guide for Calculation of Greenhouse Gas Emissions (OCCC 2018), are equivalent to $\mathrm{CO}_{2}$ emissions from 5,233,283 motor vehicles in one hour or 218,053 motor vehicles in 24 hours.

\section{Discussion}

\section{$4.1 \quad$ Economics challenges}

Research has shown that manual wood pellet production in small quantities is not economically feasible, with an annual cost of more than 60,000 euros. Even considering the economic savings obtained by using this wood biofuel in sustainable heating systems installed buildings, the result shows about 50,000 euros of annual losses. This is only justified with employment creation rate and the reuse of a green waste, whose savings, for the management of $49,000 \mathrm{~kg}$ of waste required in the first phase, were estimated at about 14,000 euros. So the final balance of the town of Serra with manual wood pellet production process, was estimated at a cost of 33,000 euros per year.

Increasing solid wood biofuel production to sell it and acquire an income that added to the economic savings (21,170.84 euros) proceeding from the use of that biofuel 
in sustainable heating systems, is in principle more expensive in terms of its production (70,224.48 euros). Despite, the sale of the surplus of wood biofuel in addition to the savings obtained by the non-use of traditional energies, together with the average annual savings in waste management, estimated at about 24,000 euros per year, allows an annual income for the municipality of Serra of 11,900 euros.

\subsection{Environmental challenges}

The use of a wood biofuel whose origin is green waste coming from gardening, agricultural or forestry works, allows to stop using fossil fuels such as diesel in the case of the public school. This is translated in the reduction of $\mathrm{CO}_{2}$ emissions into the atmosphere of $72,321 \mathrm{~kg}$. In the case of the public buildings of Town Hall and the Public nursery, 74,624 $\mathrm{kWh}$ and $97,209 \mathrm{kWh}$, respectively of electricity, were no longer consumed. The savings in $\mathrm{CO}_{2}$ emissions into the atmosphere have been estimated at a total of $57,295 \mathrm{~kg}$. Therefore the total $\mathrm{CO}_{2}$ emissions avoided in the atmosphere by consuming a biofuel of renewable origin has been $129,616 \mathrm{~kg}$ or $61,673 \mathrm{~kg} /$ year.

The research also considers $\mathrm{CO}_{2}$ emissions savings obtained from using that wood biofuel (Vanneste et al. 2011) in other sustainable heating installations other than those existing in public buildings. For a sustainable use of 1,000 tons of wood pellet production per year, an average of $1,148,000 \mathrm{~kg}$ of $\mathrm{CO}_{2}$ emissions is avoided annually. So the total amount of $\mathrm{CO}_{2}$ that is no longer emitted into the atmosphere by the use of a locally sourced green fuel and its sale in nearby areas, is about 1,200 tons per year. For all of the above, it is possible to conclude that the use of a local and renewable biofuel contributes directly to the reduction of greenhouse gas emissions into the atmosphere. It should be remembered here that the $\mathrm{CO}_{2}$ emissions balance of biomass use is considered neutral as the $\mathrm{CO}_{2}$ emitted into the atmosphere during combustion is the same as that used by biomass for its growth (Zanchi et al. 2011).

\subsection{Energy - technological challenges}

Implementing a new energy model based on the energy use of a solid wood biofuel, in a municipality of 3,000 inhabitants, has been an energy and technological challenge, in which it is necessary to highlight a series of errors and difficulties that appeared mostly during the first phases of the project, to avoid repeating them in case of replicating the model in other areas or areas of similar characteristics.

The first wood biofuel generated was a mix of wood chips coming from various wastes whose density and calorific power were scarce, requiring a manual screening and causing jamming problems in the feeding systems of the boilers. Similarly, the lack of consistency of this highly heterogeneous mix in its shape and composition caused the formation of domes inside the silo, which after several failed attempts was solved by installing a vibrator module attached to the silo wall.

The need for supplementary screening and the high frequency to fill up of the silo, due to that wood chips low calorific power, resulted in a demand for additional efforts by municipal operators and low acceptance of the project.
Table 12

Characteristics of wood pellet produced during the research period.

\begin{tabular}{lrr}
\hline Parameter & $\begin{array}{r}\text { Average } \\
\text { Results }\end{array}$ & Units \\
\hline Average diameter & 6.35 & $\mathrm{~mm}$ \\
Average length & 12.9 & $\mathrm{~mm}$ \\
Fine percentage $(<3,15 \mathrm{~mm})$ & 1.59 & $\%$ \\
Bulk density & 593 & $\mathrm{Kg} / \mathrm{m}^{3}$ \\
Moisture & 9.68 & $\%$ \\
Ashes & 2.07 & $\%$ \\
High calorific power & $4,266.20$ & $\mathrm{Cal} / \mathrm{g}$ \\
Low calorific power & $3,925.81$ & $\mathrm{Cal} / \mathrm{g}$ \\
Chlorine & 0.06 & $\%$ \\
Nitrogen & 0.29 & $\%$ \\
Sulfur & 0.03 & $\%$ \\
\hline
\end{tabular}

Manual production of pellet with small machinery involved a number of risks and difficulties that must be avoided as much as possible. Low price machinery had a lack of quality and safety, which resulted in the replacement of some pieces locally manufactured, which led to problems in terms of manufacturing times and interruption of wood biofuel production.

It is worth noting the independence of the type of fuel of the installed heating systems, the boilers installed, being poly combustible, allowed the use of wood chips and subsequently moving to wood pellet, changing only the fuel dose and the frequency of feeding. Automatic ash cleaning systems and smoke tubes facilitated maintenance labours that should be carried out. Finally, it is necessary to highlight the ease of operation of the school boiler thanks to its connection via modem so that it can be controlled from any terminal or electronic device.

Investment in a semi-industrial pelletizing prototype line, completely eliminated the difficulties of manual operation and safety related risks. It also ensured homogeneous and quality production of wood pellets (Table 12) and allowed the increase in production to cover municipal needs. The surplus of wood pellets is sold locally encouraging the use of a renewable energy source and the replacement of old heating systems with new biomasspowered ones.

\section{Conclusions}

An adequate management of green waste in agroforestry areas, such as the one coming from gardening, agricultural operations and forest fire prevention works, transported and stored in a single point. Where it is processed to generate a solid biofuel, such as wood pellets, capable to be used in sustainable heating systems in public buildings. All this carried out by public administration itself. It has as direct consequences to a certain economic savings in green waste management and energy bills, in addition, this waste management and the use of a renewable biofuel has a number of other advantages such as reducing greenhouse gas emissions, implementing forest fire defense infrastructures and generating employment. However, the scale those projects are carried makes these more or less economically viable, so local level projects in agroforestry areas are possible, 
although with some public investments, mainly personnel costs and equipment depreciation. Political leaders are left to assess whether this expenditure is offset by job creation, management of natural regions, and a bet on renewable energy generated and consumed at local level.

\section{References}

Agencia EFE. (2012). España cifra en 90 millones las pérdidas en Cortes de Pallás y Andilla. Levante emv 16-07-2012; https://www.levante-emv.com/comunitatvalenciana/2012/07/16/espana-cifra-90-millones-perdidas12968097.html

Carrillo-Parra, A., Contreras-Trejo, J.C., Pompa-García, M., Pulgarín-Gámiz, M.Á., Rutiaga-Quiñones, J.G., PámanesCarrasco, G., Ngangyo-Heya, M. (2020). Agro-Pellets from Oil Palm Residues/Pine Sawdust Mixtures: Relationships of Their Physical, Mechanical and Energetic Properties, with the Raw Material Chemical Structure. Appl. Sci, 10, 6383;

Deb U., Bhuyan N., Bhattacharya S., and Kataki R. (2019). Agro-residues and weed biomass as a source bioenergy: Implications for sustainable management and valorization of low-value biowastes, International Journal of Renewable Energy Development, $\quad$ 8(3), 243-251; https://doi.org/10.14710/ijred.8.3.243-251

Generalitat Valenciana. (2001) Decreto 77/2001, de 2 de abril, del Consell, por el que se aprueba el Plan de Ordenación de los Recursos Naturales de la Sierra Calderona. Texto integro. Vol. I. Introduction, 14.

Generalitat Valenciana. (2001). Decreto 77/2001, de 2 de abril, del Consell, por el que se aprueba el Plan de Ordenación de los Recursos Naturales de la Sierra Calderona. Texto integro. Vol. III Diagnostic, S1. 1-2.

Giménez, I. Asociación Española de Valorización Energética de la Biomasa, AVEBIOM. (2018). Astillas "kilómetro cero" en el vallès occidental. Bioenergy International, ${ }^{\circ} 41,22-24$.

Giorio Ch., Pizzini S., Marchiori E., Piazza R., Grigolato S., Zanetti m., Cavalli R., Simoncin M., Soldà L., Badocco D., Tapparo A. (2019). Sustainability of using vineyard pruning residues as an energy source: Combustion performances and environmental impact, Fuel, 243, 371-380;

Giurea, R., Precazzini, I., Ragazzi, M., Achim, M.I., Cioca, L.-I., Conti, F., Torretta, V., Rada, E.C. (2018). Good Practices and Actions for Sustainable Municipal Solid Waste Management in the Tourist Sector. Resources, 7, 51.

IDAE Instituto para la Diversificación y Ahorro de la Energía. Ministerio de Industria, Turismo y Comercio. (2007). Energía de la biomasa. chap. 2, 19-31;

Jekayinfa, S.O., Orisaleye, J.I., Pecenka, R. (2020). An Assessment of Potential Resources for Biomass Energy in Nigeria. Resources, 9, 92;

Kolovos K., Kyriakopoulos G., M. S. Chalikias M. (2011). Coevaluation of basic wood fuel types used as alternative heating sources to existing energy network. Journal of Environmental Protection and Ecology, 12 (2), 733-742.

Kyriakopoulos G, Chalikias M. (2013). The Investigation of Woodfuels' Involvement in Green Energy Supply Schemes at Northern Greece: The Model Case of the Thrace Prefecture. Procedia Technology, 8, 445-452;

Kyriakopoulos G. (2010). European and international policy interventions of implementing the use of wood fuels in bioenergy sector: a trend analysis and a specific wood fuels' energy application. International Journal of Knowledge and Learning, 6(1), 43-54.

Kyriakopoulos G., Arabatzis G., Tsialis P., Ioannou K. (2018). Electricity consumption and RES plants in Greece: Typologies of regional units. Renewable Energy, 127, 134144; https://doi.org/10.1016/j.renene.2018.04.062

Martín-Gamboa, M., Dias, L.C., Quinteiro, P., Freire, F., Arroja, L., Dias, A.C. (2019). Multi-Criteria and Life Cycle Assessment of Wood-Based Bioenergy Alternatives for
Residential Heating: A Sustainability Analysis. Energies, 12, 4391.

Martinho, V.J.P.D. (2019) Socioeconomic Impacts of Forest Fires upon Portugal: An Analysis for the Agricultural and Forestry Sectors. Sustainability, 11, 374;

MAPAMA Ministerio de Agricultura, Pesca y Alimentación. Dirección General de Desarrollo Rural, Innovación y Política Forestal. (2019). Los Incendios forestales en España Decenio 2006-2015, 18; https://www.mapa.gob.es/es/desarrollorural/estadisticas/incendios-decenio-2006-2015 tcm30511095.pd

Miranda, T., Montero, I., Sepúlveda, F.J., Arranz, J.I., Rojas, C.V., Nogales, S. (2015). A Review of Pellets from Different Sources. Materials, 8, 1413-1427.

Morresi, D., Vitali, A., Urbinati, C., Garbarino, M. (2019). Forest Spectral Recovery and Regeneration Dynamics in StandReplacing Wildfires of Central Apennines Derived from Landsat Time Series. Remote Sens, 11, 308;

National Institute of Statistics of Spain. (2020). Official population figures at first of January 2020, Municipal Detail. https://www.ine.es/jaxiT3/Datos.htm?t=2903\#!tabs-tabla

Nunes, L.J.R., Matias, J.C.O. (2020). Biomass Torrefaction as a Key Driver for the Sustainable Development and Decarbonization of Energy Production. Sustainability, 12; 922.

OCCC Oficina Catalana del Canvi Climàtic. (2018) Guia pràctica per al càlcul d'emissions de gasos amb efecte d'hivernacle (GEH),

13-28; https://canviclimatic.gencat.cat/web/.content/04 ACTUA/Co m_calcular_emissions_GEH/guia_de_calcul_demissions_de_c o2/190301_Guia-practica-calcul-emissions_CA.pdf

Pausas J. G., Llovet J., Rodrigo A., Vallejo R. (2008) Are wildfires a disaster in the Mediterranean basin? - A review. International Journal of Wildland Fire 17, 713-723;

Pawłat-Zawrzykraj, A., Podawca, K. (2020). Diversification of Municipalities Located in the Impact Area of National Parks in Terms of Environmental Requirements of Sustainable Tourism. Sustainability, 12, 4896 .

Picchio, R., Latterini, F., Venanzi, R., Stefanoni, W., Suardi, A.; Tocci, D., Pari, L. (2020). Pellet Production from Woody and Non-Woody Feedstocks: A Review on Biomass Quality Evaluation. Energies, 13, 2937.

Preiss, E., Martin, J., Debussche, M. (1997). Rural depopulation and recent landscape changes in a Mediterranean region: Consequences to the breeding avifauna. Landscape Ecol 12, $51-61$;

Regos, A., Aquilué, N., López, I. et al. (2016). Synergies Between Forest Biomass Extraction for Bioenergy and Fire Suppression in Mediterranean Ecosystems: Insights from a Storyline-and-Simulation Approach. Ecosystems 19, 786-802; https://doi.org/10.1007/s10021-016-9968-z

Ronzon, T., Piotrowski, S., Tamosiunas, S., Dammer, L., Carus, M., M'barek, R. (2020). Developments of Economic Growth and Employment in Bioeconomy Sectors across the EU. Sustainability, 12, 4507.

Streimikiene, D., Lekavičius, V., Baležentis, T., Kyriakopoulos, G.L., Abrhám, J.(2020). Climate Change Mitigation Policies Targeting Households and Addressing Energy Poverty in European Union. Energies, 13, 3389;

Thek G., Obernberger I., (2004). Wood pellet production costs under Austrian and in comparison to Swedish framework conditions, Biomass and Bioenergy, 27(6), 671-693;

Vanneste J., Van Gerven T., Vander Putten E., Van der Bruggen B., Helsen L., (2011). Energetic valorisation of wood waste: Estimation of the reduction in $\mathrm{CO}_{2}$ emissions, Science of The Total Environment, 409(19), 3595-3602;

Varga, D. (2020). Are Agrarian Areas in Mediterranean Mountain Regions Becoming Extinct? A Methodological Approach to Their Conservation. Forests, 11, 1116;

Visser, L.; Hoefnagels, R.; Junginger, M. (2020). The Potential Contribution of Imported Biomass to Renewable Energy Targets in the EU-the Trade-off between Ambitious 
Citation: Mayans, J.J., Torrent-Bravo, J.A., and López L., (2021) Energy use of Mediterranean forest biomass in sustainable public heating systems and its effects on climate change - case of study. Int. Journal of Renewable Energy Development, 10(2), 229-238, doi: 10.14710/ijred.2021.34276

Page | 238

Greenhouse Gas Emission Reduction Targets and Cost Thresholds. Energies, 13, 1761.

Bujdosó Z., Patkós C., Kovács T., Radics Z., and Baros Z. (2012).

The Social Aspects and Public Acceptance of Biomass Giving the Example of a Hungarian Region, International Journal of Renewable Energy Development, 1(2), 39-43;

Zanchi, G., Pena, N. and Bird, N. (2011), Is woody bioenergy carbon neutral? A comparative assessment of emissions from consumption of woody bioenergy and fossil fuel. Glob. Change Biol. Bioenergy, 4, 761-772;

Zvingilaite E, Balyk O. (2014) Heat savings in buildings in a 100\% renewable heat and power system in Denmark with different shares of district heating, Energy and Buildings, 82, 173-186,; https://doi.org/10.1016/j.enbuild.2014.06.046. 